\title{
INTERAKSI GENOTIPE X MUSIM KARAKTER FISIOLOGI LATEKS DAN DAYA HASIL BEBERAPA GENOTIPE KARET HASIL PERSILANGAN TAHUN 1992
}

\author{
The Genotype x Season Interaction of Latex Physiology Characters and Yield Potential of Some Rubber \\ Genotypes Crossing Result in 1992
}

\author{
Sayurandi ${ }^{1}$, Desta Wirnas ${ }^{2}$, dan Sekar Woelan ${ }^{3}$ \\ ${ }^{1}$ Balai Penelitian Sungei Putih, Pusat Penelitian Karet, P.O. Box 1415, Medan 20001 \\ ${ }^{2}$ Program Studi Agronomi dan Hortikultura, Institut Pertanian Bogor, \\ Jl. Meranti No. 1, Bogor 16680 \\ ${ }^{3}$ Pusat Penelitian Karet, Jl. Salak No.1 Bogor 16151 \\ Email: sayurandi_sp@yahoo.com
}

Diterima 26 Juli 2017 / Direvisi 29 Jan 2018 / Disetujui 28 Februari 2018

\begin{abstract}
Abstrak
Karakter fisiologi lateks dan daya hasil sangat dipengaruhi oleh faktor genotipe, lingkungan, dan interaksi keduanya. Kondisi lingkungan yang paling berpengaruh terhadap karakter fisiologi dan daya hasil salah satunya adalah jumlah hari hujan bulanan. Tujuan penelitian ini adalah untuk memperoleh informasi tentang keragaan karakter fisiologi lateks dan daya hasil beberapa genotipe karet harapan hasil persilangan tahun 1992 pada periode bulan kering dan basah. Rancangan penelitian yang digunakan dalam penelitian ini adalah rancangan acak lengkap (RAL) dua faktor dengan tiga ulangan. Faktor pertama adalah genotipe yang terdiri dari 15 genotipe karet harapan dan dua klon pembanding yaitu PB 260 dan RRIC 100. Faktor kedua adalah musim yang terdiri dari bulan basah (bulan Agustus - November 2015) dan bulan kering (bulan Januari - Maret 2016) menurut klasifikasi Oldeman. Hasil penelitian menunjukkan bahwa interaksi genotipe dengan musim berpengaruh nyata terhadap kadar sukrosa, fosfat anorganik, tiol, kecepatan aliran lateks, indeks penyumbatan, indeks hasil dan hasil lateks. Genotipe HP 92/542 merupakan genotipe yang lebih toleran terhadap perubahan musim dengan hasil lateks yang tinggi dan stabil. Diharapkan genotipe tersebut dapat dikembangkan sebagai materi genetik klon unggul baru. Genotipe HP
\end{abstract}

92/726 juga toleran terhadap perubahan musim namun hasil lateksnya rendah, sedangkan genotipe HP 92/838 tidak toleran terhadap perubahan musim dengan hasil lateks rendah dan tidak stabil.

Kata kunci: Hevea brasiliensis, genotipe, karakter fisiologi, hasil lateks, bulan kering dan basah.

\section{Abstract}

Latex physiology characters and yield potential of rubber tree (Hevea brasiliensis Muell. Arg.) are determined by genetic factor, environments, and genotype $x$ environment interaction. The environmental conditions greatly influence latex physiology characters and latex yield potential are the monthly rainfalls. The objective of the research was to get information about the performance of latex physiology characters and yield potential of some promising rubber genotypes of crossing results in 1992 in dry and wet months period. The experimental design used was randomize completely design (RCD) with two factors and three replications. The first factor was genotypes consisted of 15 genotypes and two control clones of PB 260 and RRIC 100. The second factor was season consisted of the wet months period (August - November 2015) and dry months period (January - March 2016) based on climate classification by Oldeman. The research result showed that the genotype $x$ season interaction effect was significant to sucrose content, 
inorganic phosphate content, thiol content, latex flow rate, plugging index, yield index, and latex yield potential. Genotype HP 92/542 was more tolerant to seasonal changes and this genotype had high latex yield and more stable. This genotype can be developed as a new genetic material of superior rubber clone. Genotype HP 92/ 726 was also tolerant to seasonal changes but the genotype had low latex yield. The genotype HP 92/838 was intolerant to seasonal changes, low latex yield and unstable.

Keywords: Hevea brasiliensis, genotype, physiology characters, dry and wet months.

\section{Pendahuluan}

Peningkatan produktivitas karet dapat dilakukan dengan cara merakit suatu klon karet unggul berdaya hasil tinggi. Genotipe karet harapan yang akan dijadikan klon karet unggul tidak cukup hanya melihat faktor genetik saja, namun pengaruh lingkungan perlu diperhatikan. Faktor lingkungan memiliki peranan yang cukup berpengaruh pada fenotipe tanaman (Sundari et al., 2016; Syukur et al., 2012). Evaluasi terhadap calon varietas baru di berbagai lingkungan perlu dilakukan agar interaksi genotipe $\mathrm{x}$ lingkungan dapat diketahui, sehingga diperoleh genotipe yang stabil maupun yang sesuai pada lingkungan spesifik (Sari et al., 2013; Duzdemir, 2011; Sharrifmoghaddasi \& Omiditabrizi, 2010). Menurut Kuswanto (2007), lingkungan tumbuh yang sesuai akan mendukung pertumbuhan dan perkembangan tanaman sehingga tanaman dapat berproduksi secara optimal. Faktor lingkungan yang dapat mempengaruhi fenotipe tanaman antara lain: kondisi suhu, cahaya, curah hujan, ketinggian tempat, dan lain-lain.

Perkebunan karet di Indonesia secara geografis tersebar di dua belahan bumi khatulistiwa, sehingga distribusi hujan berbeda pada setiap bulannya. Distribusi hujan yang berbeda menyebabkan pola produksi karet aktual di Indonesia sangat berfluktuasi. Produksi karet menurun pada semester pertama di wilayah bagian utara khatulistiwa memasuki musim kemarau seperti yang terjadi di Provinsi Aceh, Sumatera Utara, dan sebagian pulau Kalimantan bagian Utara, sedangkan produksi karet meningkat di bagian selatan khatulistiwa yang memasuki musim hujan seperti di Provinsi Riau, Sumatera Barat, Jambi, Bengkulu, Sumatera Selatan, Lampung, dan pulau Jawa. Sebaliknya, produksi karet meningkat pada semester kedua di wilayah bagian utara dan menurun pada wilayah bagian selatan karena disebabkan perubahan distribusi curah hujan yang mempengaruhi ketersediaan air dan fase gugur daun (Junaidi et al., 2015).

Beberapa penelitian membuktikan bahwa faktor agroklimat seperti curah hujan sangat menentukan produktivitas tanaman karet (Roux et al., 2000; Ardika et al., 2016; Cahyo et al., 2016; Gireesh et al., 2011). Menurut Siregar (2014), seiring dengan perubahan musim, tanaman karet secara periodik mengalami gugur daun pada musim kemarau dan pembentukan daun sempurna terjadi pada saat musim hujan. Kondisi tersebut sangat mempengaruhi produktivitas tanaman. Kasus pada tanaman perkebunan, cekaman kekeringan menyebabkan pertumbuhan tanaman kakao melambat dan produksinya menjadi rendah (Prihastanti et al., 2015). Kondisi kelapa sawit yang kekurangan air berakibat terhadap daun muda tidak membuka, pelepah daun menua sampai pupus patah, dan menurunkan produksi kelapa sawit mencapai $10-40 \%$. Klon karet seri RRIC dan RRISL di Sri Lanka menunjukkan adanya respon klon terhadap perubahan musim (Gunasekera et al., 2013).

Penelitian tentang pengaruh musim terhadap produktivitas karet di Indonesia masih sangat terbatas. Pengujian-pengujian klon pada umumnya belum mempertimbangkan respon tiap klon secara spesifik terhadap perubahan musim, meskipun sudah banyak klon unggul ditanam pada berbagai lokasi perkebunan. Sejauh ini, laporanlaporan kinerja klon yang sedang diuji belum menyajikan adanya dinamika produksi karet menurut musim yang salah satunya adalah pengujian genotipe karet harapan hasil persilangan 1992 (HP 92) di pengujian Plot 
Promosi PP/07/04 (Woelan et al., 2013; Sayurandi, 2016). Menurut Wijaya (1996), daerah karet dengan curah hujan rendah $(<1500 \mathrm{~mm} / \mathrm{th})$ berpotensi mengganggu keragaan klon, karena defisit air yang tidak mencukupi kebutuhan tanaman.

Hasil pengujian genotipe karet HP 92 di Kebun Percobaan Balai Penelitian Sungei Putih menghasilkan sejumlah genotipe potensial yang saat ini masih dalam proses evaluasi (Woelan et al., 2012) . Potensi hasil lateks dari genotipe karet harapan tersebut memperlihatkan hasil lateks lebih tinggi dibandingkan dengan klon pembanding. Namun masing-masing genotipe memiliki hasil lateks cukup beragam di setiap bulannya. Kondisi curah hujan yang berbeda di setiap bulan diduga menjadi penyebab hasil lateks masing-masing genotipe menjadi beragam. Dengan demikian, respon genotipe terhadap perubahan musim tentunya perlu diketahui karena hasil lateks merupakan karakter kuantitatif yang sangat dipengaruhi oleh perubahan musim.

Karakter fisiologi lateks berpengaruh terhadap hasil lateks (Woelan et al., 2013). Menurut Sumarmadji (1999) metabolisme pembentukan partikel karet dipengaruhi oleh beberapa karakter fisiologi yang dapat dideteksi dengan diagnosis lateks. Kandungan lateks dari jaringan kulit yang dapat digunakan untuk mendiskripsikan karakter fisiologi lateks adalah kadar sukrosa, fosfat anorganik, tiol, $\mathrm{pH}$ lateks, kadar karet kering dan indeks penyumbatan. Sukrosa merupakan indikator yang penting karena merupakan prekursor untuk mensintesis partikel karet, fosfat anorganik merupakan indikator untuk proses metabolisme, dan tiol merupakan aktivator berbagai enzim yang diperlukan untuk kestabilan membran lutoid (Atminingsih, 2015).

Penelitian ini bertujuan untuk memperoleh informasi keragaan karakter fisiologi lateks dan daya hasil beberapa genotipe karet harapan hasil persilangan tahun 1992 pada periode bulan kering dan basah.

\section{Bahan dan Metode}

Penelitian ini dilakukan pada bulan Agustus 2015 - Maret 2016. Penelitian menggunakan materi genetik HP 92 di pengujian plot promosi PP/07/04 di Kebun Percobaan Balai Penelitian Sungei Putih, Pusat Penelitian Karet pada tahun 2004. Rancangan percobaan yang digunakan yaitu rancangan acak lengkap (RAL) dua faktor dengan tiga ulangan. Faktor pertama adalah genotipe karet harapan sebanyak 15 genotipe yaitu HP 92/109, HP 92/179, HP 92/211, HP 92/309, HP 92/327, HP 92/366, HP 92/368, HP 92/388, HP 92/542, HP 92/669, HP 92/677, HP 92/704, HP 92/ 711, HP 92/726, dan HP 92/838 serta 2 klon pembanding PB 260 dan RRIC 100. Faktor kedua adalah faktor musim yaitu periode bulan basah (Agustus November 2015) dan periode bulan kering (Januari - Maret 2016) menurut klasifikasi Oldeman. Menurut sistem klasifikasi Oldeman bulan kering adalah jumlah curah hujan bulanan $\leq 100 \mathrm{~mm} /$ bulan dan bulan basah yaitu jumlah curah hujan bulanan $\geq 200$ $\mathrm{mm} /$ bulan (Kartasapoetra, 1986). Kondisi jumlah curah hujan dan hari hujan bulanan yang diamati pada saat penelitian di lokasi pengujian genotipe karet disajikan pada Gambar 1, sedangkan kondisi kelembaban udara dan suhu udara disajikan pada Gambar 2.

Masing-masing genotipe terdiri dari 60 tanaman dan setiap ulangan terdiri dari 20 tanaman. Masing-masing genotipe ditanam dengan menggunakan jarak tanam $5 \mathrm{~m} \mathrm{x} 4 \mathrm{~m}$. Pengamatan dilakukan pada masing-masing genotipe berumur 11 tahun yaitu dengan cara mengamati setiap parameter pada periode bulan kering dan bulan basah. Parameter yang diamati meliputi: kecepatan aliran lateks, indeks penyumbatan, kadar fosfat anorganik, kadar sukrosa, kadar tiol, kadar karet kering, indeks hasil, dan hasil lateks. Sistem sadap yang digunakan yaitu sistem sadap $\mathrm{S} / 2 \mathrm{~d} 3$. Waktu pengamatan hasil lateks di bulan basah dilakukan pada bulan Agustus - November 2015, sedangkan pengamatan hasil lateks di 


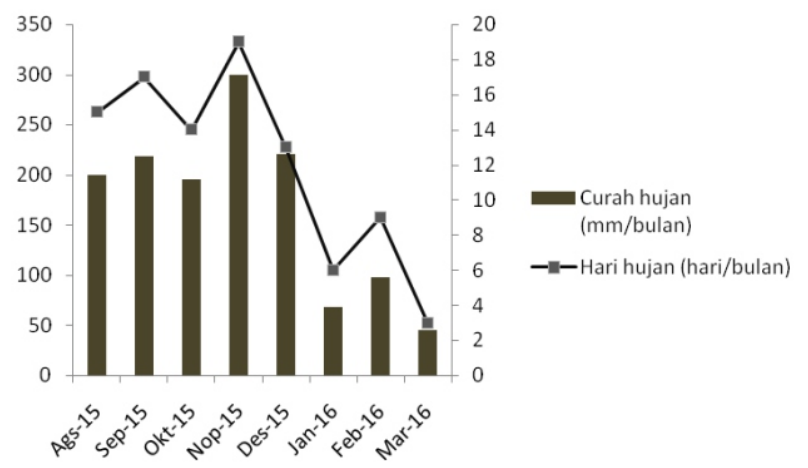

Gambar 1. Jumlah curah hujan dan hari hujan pada bulan Agustus 2015 - Maret 2016 di lokasi penelitian.

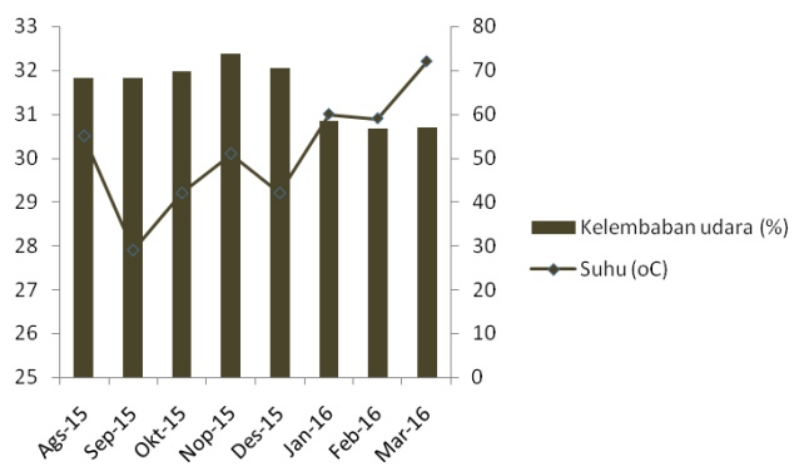

Gambar 2. Kelembaban udara dan suhu udara pada bulan Agustus 2015 - Maret 2016 di lokasi penelitian

bulan kering dilakukan pada bulan Januari Maret 2016. Data hasil lateks diambil setiap tiga hari sekali. Pengamatan untuk sifat aliran lateks (kecepatan aliran lateks, indeks penyumbatan, dan indeks hasil) dan karakter fisiologi lateks (kadar sukrosa, kadar tiol, kadar fosfat anorganik, dan kadar karet kering) diamatipadasetiapbulannya. $M$ e $t$ o d e pengamatan pada masing-masing parameter dilakukan sebagai berikut:

1) Kecepatan aliran lateks, dihitung dengan menggunakan metode Milford (1969) yaitu membandingkan volume lateks ( $\mathrm{ml}$ ) yang mengalir pada lima menit pertama dalam satu kali sadap dengan panjang alur sadapan $(\mathrm{cm})$ dikali 0,5 .

2) Indeks penyumbatan, diamati dengan menggunakan metodeMilford (1969) yaitu membandingkan volume lateks yang mengalir selama 5 menit pertama yang dihasilkan dalam satu kali sadap dengan total volume lateks dikali 100\%.
3) Kadar fospat anorganik diukur menggunakan metode (Taussky \& Shorr, 1953) yaitu berdasarkan prinsip reaksi dengan molibdat menghasilkan kompleks Pi-molibdat berwarna biru yang terabsorsi pada panjang gelombang $\lambda 750 \mathrm{~nm}$ dengan alat spektrofotometer Beckham DU 650 .

4) Kadar sukrosa diukur menggunakan metode Dische (1962), yaitu berdasarkan reaksinya dengan anthrone menghasilkan turunan furfural yang berwarna hijau biru yang terabsorbsi pada panjang gelombang $\lambda 627 \mathrm{~nm}$.

5) Kadar tiol, diukur menggunakan metode McMullen (1960) yaitu serum TCA berdasarkan prinsip reaksinya dengan asam dithiobis-nitrobenzoat (DNTP) untuk membentuk TNB yang berwarna kuning yang terabsorbsi pada $\lambda 412 \mathrm{~nm}$ dengan spektrofotometer Beckman DU 650. 
6) Kadar karet kering, diukur dengan beberapa tetes contoh lateks segar pada gelas objek, ditimbang bobot basahnya, kemudian dioven selama kurang lebih $1 \mathrm{x}$ 24 jam dengan suhu sekitar $100^{\circ} \mathrm{C}$ sehingga bobotnya tidak berubah lagi. Nilai kadar karet kering adalah bobot kering dibagi dengan bobot basah dan dikalikan dengan 100\%(Woelan etal., 2014).

7) Indeks hasil, dihitung dengan cara m e n g k u r volu m e 1 a t e k s (ml/pohon/sadap) dibagi dengan ukuran lilit batang tanaman dikali 100\% (Woelan $e t$ al., 2014).

8) Hasil lateks, diamati dengan cara menyadap kulit pada panel BO-2 (bark orginal pada panel kedua). Penyadapan pada panel BO-2 dilakukan pada ketinggian panel sadap $\pm 100 \mathrm{~cm}$ di atas pertautan okulasi. Untuk mengetahui hasil karet kering per pohon maka dilakukan dengan cara mengukur volume lateks dengan gelas ukur dan dikalikan dengan kadar karet kering pada masing-masing genotipe yang dinyatakan dalam bentuk gram/pohon/sadap (g/p/s).

Analisis data dilakukan pada semua parameter dengan menggunakan analisis ragam (Anova). Jika perlakuan menunjukkan pengaruh nyata maka dilakukan uji lanjut dengan menggunakan Honest Significance Difference (HSD) (Mattjik \& Sumertajaya, 2006).

\section{Hasil dan Pembahasan}

\section{Keragaan karakter fisiologi lateks beberapa genotipe karet harapan.}

Berdasarkan hasil analisis ragam (Tabel 1) menunjukkan bahwa interaksi genotipe $\mathrm{x}$ musim berpengaruh nyata terhadap kadar sukrosa, kadar fosfat anorganik, kadar tiol, kecepatan aliran lateks, dan indeks penyumbatan. Tabel 2 menunjukkan bahwa respon genotipe sangat peka terhadap perubahan musim. Kondisi curah hujan diduga menjadi salah satu penyebab terjadinya respon yang berbeda pada masing-masing genotipe. Genotipe HP 92/309 memiliki kadar sukrosa lebih tinggi di bulan basah $(17,82 \mathrm{mM})$ dibandingkan dengan klon pembanding $\mathrm{PB}$ 260 , sedangkan genotipe lainnya memiliki kadar sukrosa tidak berbeda nyata dengan klon pembanding PB 260. Semua genotipe memiliki kadar sukrosa tidak berbeda nyata dengan klon PB 260 di bulan kering. Berdasarkan karakter kadar sukrosa menunjukkan genotipe HP 92/309 dan HP 92/711 sangat peka terhadap perubahan musim. Hal ini terlihat dari kadar sukrosa pada kedua genotipe tersebut tergolong tinggi saat kondisi bulan basah, namun menurun sangat nyata saat kondisi bulan kering.

Menurut Purwaningrum (2016), kadar sukrosa tinggi di bulan basah diduga disebabkan kondisi daun telah berkembang sempurna, sehingga fungsi daun sebagai

Tabel 1. Sidik ragam karakter kadar sukrosa, kadar fosfat anorganik, kadar tiol, kecepatan aliran lateks, dan indeks penyumbatan 15 genotipe karet

\begin{tabular}{ccccccc}
\hline $\begin{array}{c}\text { Sumber } \\
\text { keragaman }\end{array}$ & $\mathrm{db}$ & $\begin{array}{c}\text { Kadar } \\
\text { sukrosa } \\
(\mathrm{mM})\end{array}$ & $\begin{array}{c}\text { Kadar fosfat } \\
\text { anorganik } \\
(\mathrm{mM})\end{array}$ & $\begin{array}{c}\text { Kadar } \\
\text { tiol } \\
(\mathrm{mM})\end{array}$ & $\begin{array}{c}\text { Kecepatan } \\
\text { aliran } \\
\text { lateks } \\
(\mathrm{ml} / \text { menit })\end{array}$ & $\begin{array}{c}\text { Indeks } \\
\text { penyumbatan } \\
(\%)\end{array}$ \\
\hline Genotipe (G) & 16 & $34,17^{* *}$ & $49,89^{* *}$ & $0,08^{* *}$ & $284,43^{* *}$ & $202,95^{* *}$ \\
Musim (M) & 1 & $59,15^{* *}$ & $656,20^{* *}$ & $0,23^{* *}$ & $442,70^{* *}$ & $1796,93^{* *}$ \\
GxM & 16 & $24,31^{* *}$ & $24,14^{* *}$ & $0,02^{*}$ & $29,15^{*}$ & $65,20^{* *}$ \\
Galat & 68 & 6,01 & 9,61 & 0,01 & 24,19 & 24,20 \\
\hline Total & 101 & & & & & \\
\hline
\end{tabular}

Tanda ${ }^{* * * *}=$ berturut-turut berbeda nyata pada $\alpha 0,05$ dan $\alpha 0,01$. 
Tabel 2. Pengaruh interaksi genotipe dan musim terhadap kadar sukrosa, kadar fosfat anorganik, dan kadar tiol 15 genotipe karet harapan

\begin{tabular}{|c|c|c|c|c|c|c|}
\hline \multirow{2}{*}{ Genotipe } & \multicolumn{2}{|c|}{$\begin{array}{l}\text { Kadar sukrosa } \\
(\mathrm{mM})\end{array}$} & \multicolumn{2}{|c|}{$\begin{array}{l}\text { Kadar fosfat anorganik } \\
\text { (mM) }\end{array}$} & \multicolumn{2}{|c|}{$\begin{array}{l}\text { Kadar tiol } \\
(\mathrm{mM})\end{array}$} \\
\hline & $\begin{array}{l}\text { Bulan } \\
\text { basah }\end{array}$ & $\begin{array}{l}\text { Bulan } \\
\text { kering }\end{array}$ & $\begin{array}{l}\text { Bulan } \\
\text { basah }\end{array}$ & $\begin{array}{l}\text { Bulan } \\
\text { kering }\end{array}$ & $\begin{array}{l}\text { Bulan } \\
\text { basah }\end{array}$ & $\begin{array}{l}\text { Bulan } \\
\text { kering }\end{array}$ \\
\hline HP 92/109 & $2,26^{\text {cd }}$ & $2,41^{\text {cd }}$ & $17,57^{\mathrm{abc}}$ & $18,03^{\mathrm{ab}}$ & $0,56^{\mathrm{bc}}$ & $0,50^{\mathrm{bc}}$ \\
\hline HP 92/179 & $3,98 b^{c d}$ & $1,89^{\mathrm{cd}}$ & $17,43^{\mathrm{abc}}$ & $17,08^{\mathrm{abc}}$ & $0,68^{\mathrm{b}}$ & $0,50^{\mathrm{bc}}$ \\
\hline HP $92 / 211$ & $7,83^{\text {bcd }}$ & $2,76^{\text {bcd }}$ & $17,50^{\mathrm{abc}}$ & $6,53^{\mathrm{de}}$ & $1,02^{\mathrm{a}}$ & $0,49^{\mathrm{bc}}$ \\
\hline HP 92/309 & $17,82^{a}$ & $6,37^{\mathrm{bcd}}$ & $12,28^{\text {abcde }}$ & $8,87^{\text {bcde }}$ & $0,47^{\mathrm{bc}}$ & $0,37^{\mathrm{bc}}$ \\
\hline HP 92/327 & $3,54^{\mathrm{bcd}}$ & $6,70^{\text {bcd }}$ & $14,22^{\mathrm{abcd}}$ & $9,13^{\text {bcde }}$ & $0,41^{\mathrm{bc}}$ & $0,31^{\mathrm{c}}$ \\
\hline HP 92/366 & $5,39^{\text {bcd }}$ & $5,75^{\text {bcd }}$ & $13,27^{\text {abcde }}$ & $6,71^{\mathrm{de}}$ & $0,35^{\mathrm{bc}}$ & $0,32^{\mathrm{c}}$ \\
\hline HP 92/368 & $4,66^{\mathrm{bcd}}$ & $2,49^{\text {bcd }}$ & $15,35^{\text {abcd }}$ & $8,42^{\text {bcde }}$ & $0,57^{\mathrm{bc}}$ & $0,41^{\mathrm{bc}}$ \\
\hline HP $92 / 388$ & $9,24^{\mathrm{bc}}$ & $7,70^{\text {bcd }}$ & $13,80^{\text {abcd }}$ & $4,02^{\mathrm{e}}$ & $0,53^{\text {bc }}$ & $0,48^{\mathrm{bc}}$ \\
\hline HP $92 / 542$ & $3,41^{\mathrm{bcd}}$ & $5,81^{\text {bcd }}$ & $20,87^{\mathrm{a}}$ & $10,07^{\text {bde }}$ & $0,57^{\mathrm{bc}}$ & $0,58^{\mathrm{bc}}$ \\
\hline HP 92/669 & $3,59^{\mathrm{bcd}}$ & $5,98^{\text {bcd }}$ & $10,55^{\text {bde }}$ & $12,85^{\text {abcde }}$ & $0,62^{\mathrm{bc}}$ & $0,55^{\mathrm{bc}}$ \\
\hline HP 92/677 & $3,51^{\mathrm{bcd}}$ & $0,93^{\mathrm{d}}$ & $14,58^{\text {abcd }}$ & $6,72^{\mathrm{de}}$ & $0,44^{\mathrm{bc}}$ & $0,42^{\mathrm{bc}}$ \\
\hline HP 92/704 & $3,69^{\mathrm{bcd}}$ & $4,99^{\text {bcd }}$ & $12,23^{\text {abcde }}$ & $8,43^{\text {bcde }}$ & $0,47^{\mathrm{bc}}$ & $0,45^{\text {bc }}$ \\
\hline HP 92/711 & $10,43^{\mathrm{ab}}$ & $1,78^{\mathrm{d}}$ & $13,13^{\text {abcde }}$ & $6,79^{\mathrm{de}}$ & $0,47^{\mathrm{bc}}$ & $0,41^{\mathrm{bc}}$ \\
\hline HP 92/726 & $4,45^{\mathrm{bcd}}$ & $4,99^{\mathrm{bcd}}$ & $13,42^{\text {abcde }}$ & $5,42^{\mathrm{de}}$ & $0,39^{\mathrm{bc}}$ & $0,39^{\mathrm{bc}}$ \\
\hline HP $92 / 838$ & $8,57^{\mathrm{bcd}}$ & $6,60^{\mathrm{bcd}}$ & $8,03^{\text {bcde }}$ & $7,73^{\text {cde }}$ & $0,43^{\text {bc }}$ & $0,34^{c}$ \\
\hline RRIC 100 & $5,48^{\text {bcd }}$ & $3,43^{\text {bcd }}$ & $9,20^{\text {bcde }}$ & $6,88^{\text {de }}$ & $0,40^{\mathrm{bc}}$ & $0,30^{\mathrm{c}}$ \\
\hline PB 260 & $4,34^{\text {bcd }}$ & $6,50^{\text {bcd }}$ & $14,15^{\text {abcd }}$ & $7,67^{\text {cde }}$ & $0,37^{\mathrm{bc}}$ & $0,34^{c}$ \\
\hline
\end{tabular}

Angka-angka pada kolom dan baris yang sama yang diikuti oleh huruf yang sama tidak berbeda nyata pada a 0,05 menurut uji $H S D$.

tempat fotosintesis yang memproduksi asimilat secara optimal dan selanjutnya didukung oleh ketersediaan air tanah yang cukup. Penurunan kadar sukrosa saat bulan kering diduga lebih disebabkan oleh terganggunya proses fotosintesis akibat kekurangan air dan seiring terjadinya gugur daun secara serentak di bulan kering. Pada umumnya genotipe karet yang diuji memiliki kadar sukrosa cukup stabil di dua musim. Hasil penelitian Atminingsih (2015) juga menunjukkan genotipe HP 92/309 memiliki kadar sukrosa paling tinggi dibandingkan genotipe lainnya pada saat kondisi daun berkembang sempurna (laten).

Genotipe yang diuji umumnya memiliki kadar fosfat anorganik cukup stabil di dua musim kecuali genotipe HP 92/211, HP 92/388, dan HP 92/542. Ketiga genotipe tersebut peka terhadap perubahan musim. Genotipe-genotipe tersebut memiliki kadar fosfat anorganik tergolong tinggi di bulan basah, namun menurun cukup nyata di saat kondisi bulan kering. Genotipe HP 92/542 memiliki kadar fosfat anorganik paling tinggi dibandingkan genotipe lainnya di periode bulan basah. Hal ini menunjukkan bahwa genotipe tersebut memiliki sumber energi yang cukup tinggi untuk mensintesis sukrosa menjadi partikel karet. Hasil penelitian Atminingsih (2015), genotipe HP 92/542 memiliki kadar fosfat anorganik paling tinggi dan sangat respon terhadap stimulansia pada kondisi daun laten. Peningkatan produksi mencapai $65 \%$ dibandingkan dengan perlakuan tanpa stimulansia. Fosfat anorganik merupakan senyawa dasar fosfor $(\mathrm{P})$ yang akan berkaitan dengan adenosin diphosphate (ADP) untuk menghasilkan adenosin triphosphate (ATP) yang merupakan sumber energi penting dalam molekul sel. Kadar fosfat anorganik tinggi pada bulan basah diduga disebabkan oleh ketersediaan air, sehingga tanaman memperoleh energi yang cukup untuk mengambil unsur $\mathrm{P}$ dari dalam tanah. 
Kandungan unsur $\mathrm{P}$ internal dan remobilisasi serta translokasinya pada tanaman sangat dipengaruhi oleh ketersediaan air (Zambrosi et al., 2012). Secara umum unsur $\mathrm{P}$ disimpan di daun dan pada kondisi tertentu dapat diremobilisasi ke bagian lain pada tubuh tanaman. Pada kondisi bulan basah dan sejalan dengan kondisi daun karet telah berkembang sempurna menyebabkan cadangan unsur $\mathrm{P}$ menjadi tinggi. Kondisi tersebut diduga menyebabkan kadar fosfat anorganik tinggi pada bulan basah. Sedangkan pada kondisi tanaman tercekam kekeringan akan berpengaruh terhadap ketersediaan dan absorbsi unsur $\mathrm{P}$ (Mirabello et al., 2013) . Tanaman yang kekurangan air dapat mengganggu proses penyerapan dan absorsi fosfor anorganik. Kondisi ini diduga menjadi penyebab mengapa fosfor anorganik rendah pada bulan kering dan sebaliknya fosfor anorganik tinggi pada bulan basah.

Interaksi genotipe $\mathrm{x}$ musim berpengaruh nyata terhadap kadar tiol. Genotipe HP 92/211 memiliki kadar tiol paling tinggi di bulan basah, namun tergolong rendah di bulan kering. Selain genotipe HP 92/211, genotipe lainnya memiliki kadar tiol tidak berbeda nyata antara bulan kering dengan bulan basah. Kadar tiol pada beberapa genotipe memperlihatkan dalam kondisi normal di bulan basah maupun di bulan kering. Menurut Schartner et al. (2014), kondisi kekeringan menyebabkan tanaman berupaya melindungi diri dengan menghasilkan senyawa metabolit termasuk di dalamnya membentuk senyawa tiol. Immobilisasi protein pada bagian tanaman yang mengalami cekaman akan lebih tinggi dibandingkan dengan tanpa cekaman. Kadar tiol yang rendah merupakan sinyal pada tanaman karet telah mengalami stres. Kadar tiol rendah ditunjukkan dengan nilai $<0,4 \mathrm{mM}$ (Sumarmadji \& Tistama, 2004). Kadar tiol yang rendah kemungkinan disebabkan oleh perlakuan penyadapan, pemberian stimulan dan stres lingkungan(Purwaningrum, 2016).

Analisis uji lanjut pengaruh interaksi genotipe $\mathrm{x}$ musim pada karakter kecepatan aliran lateks dan indeks penyumbatan tertera pada Tabel 3. Terdapat interaksi genotipe $\mathrm{x}$ musim pada karakter kecepatan aliran lateks

Tabel 3. Pengaruh interaksi genotipe dan musim terhadap kecepatan aliran lateks dan indeks penyumbatan 15 genotipe karet harapan.

\begin{tabular}{|c|c|c|c|c|}
\hline \multirow[t]{2}{*}{ Genotipe } & \multicolumn{2}{|c|}{$\begin{array}{c}\text { Kecepatan aliran lateks } \\
(\mathrm{ml} / \mathrm{menit})\end{array}$} & \multicolumn{2}{|c|}{$\begin{array}{l}\text { Indeks penyumbatan } \\
(\%)\end{array}$} \\
\hline & Bulan basah & Bulan kering & Bulan basah & Bulan kering \\
\hline HP 92/109 & $17,14^{\text {abcdef }}$ & $16,90^{\text {abcdef }}$ & $15,74^{\text {fgh }}$ & $26,87^{\text {abcdef }}$ \\
\hline HP 92/179 & $17,70^{\text {abcdef }}$ & $14,13^{\text {bcdef }}$ & $15,53^{\text {fgh }}$ & $37,20^{\mathrm{ab}}$ \\
\hline HP 92/211 & $18,38^{\text {abcde }}$ & $14,44^{\text {bcdef }}$ & $19,28^{\text {defgh }}$ & $36,24^{\mathrm{abc}}$ \\
\hline HP 92/309 & $23,81^{\text {abcd }}$ & $17,47^{\text {abcde }}$ & $20,78^{\text {cdefgh }}$ & $25,67^{\text {abcdefg }}$ \\
\hline HP 92/327 & $11,52^{\text {bcdef }}$ & $7,85^{\text {def }}$ & $17,37^{\text {efgh }}$ & $20,05^{\text {defgh }}$ \\
\hline HP 92/366 & $26,97^{\mathrm{ab}}$ & $21,83^{\text {abcde }}$ & $32,39^{\text {abcdef }}$ & $40,76^{\mathrm{a}}$ \\
\hline HP 92/368 & $15,89^{\text {bcdef }}$ & $9,90^{\text {cdef }}$ & $16,28^{\text {fgh }}$ & $22,24^{\text {bcdefgh }}$ \\
\hline HP 92/388 & $11,39^{\text {bcdef }}$ & $14,40^{\text {bcdef }}$ & $14,95^{\mathrm{fgh}}$ & $22,06^{\text {bdefgh }}$ \\
\hline HP 92/542 & $33,10^{\mathrm{a}}$ & $32,95^{\mathrm{a}}$ & $28,81^{\text {abcdef }}$ & $27,07^{\text {abcdef }}$ \\
\hline HP 92/669 & $25,40^{\mathrm{abc}}$ & $14,32^{\text {bcdef }}$ & $19,27^{\text {defgh }}$ & $30,44^{\text {abcdef }}$ \\
\hline HP 92/677 & $10,25^{\text {cdef }}$ & $9,53^{\text {cdef }}$ & $15,36^{\mathrm{fgh}}$ & $23,41^{\text {bcdefgh }}$ \\
\hline HP 92/704 & $13,67^{\text {bddef }}$ & $5,51^{\mathrm{f}}$ & $17,28^{\text {efgh }}$ & $22,49^{\text {bcdefgh }}$ \\
\hline HP 92/711 & $9.58^{\text {cdef }}$ & $7,24^{\mathrm{ef}}$ & $8.41^{\mathrm{h}}$ & $26,25^{\text {abcdefg }}$ \\
\hline HP 92/726 & $7,52^{\text {def }}$ & $5,34^{\mathrm{f}}$ & $15,74^{\mathrm{fgh}}$ & $19,77^{\text {defgh }}$ \\
\hline HP 92/838 & $9,38^{\text {cdef }}$ & $9,85^{\text {cdef }}$ & $10,28^{\mathrm{gh}}$ & $14,70^{\mathrm{fgh}}$ \\
\hline RRIC 100 & $22,21^{a b c}$ & $7,57^{\mathrm{def}}$ & $19,27^{\text {defgh }}$ & $35,16^{\text {abcd }}$ \\
\hline PB 260 & $11,29^{\text {bcdef }}$ & $5,12^{\mathrm{f}}$ & $16,83^{\text {efgh }}$ & $15,87^{\text {fgh }}$ \\
\hline
\end{tabular}

Angka-angka pada kolom dan baris yang sama yang diikuti oleh huruf yang sama tidak berbeda nyata pada a 0,05 menurut uji $H S D$. 
dan indeks penyumbatan. Hal ini menandakan bahwa karakter tersebut sangat peka terhadap perubahan musim. Kondisi bulan basah memberikan respon yang lebih tinggi pada karakter kecepatan aliran lateks pada hampir semua genotipe. Genotipe HP 92/542 memiliki kecepatan aliran lateks lebih tinggi dibandingkan klon PB 260 di bulan basah. Sedangkan genotipe HP 92/309, HP 92/366, dan HP 92/542 memiliki kecepatan aliran lateks lebih tinggi dibandingkan PB 260.

Klon RRIC 100 sangat peka terhadap perubahan musim. Klon RRIC 100 memiliki kecepatan aliran lateks tergolong tinggi di bulan basah, namun tergolong rendah di bulan kering. Genotipe HP 92/542 memiliki kecepatan aliran lateks paling stabil di dua musim dan cukup toleran terhadap perubahan musim. Menurut Atminingsih (2015) bahwa aliran lateks ditentukan oleh besarnya tekanan turgor, transfer air dari floem ke pembuluh lateks, dan proses koagulasi lateks.

Analisis uji lanjut menunjukkan bahwa terdapat pengaruh interaksi genotipe $\mathrm{x}$ musim pada karakter indeks penyumbatan. Klon karet diharapkan memiliki indeks penyumbatan rendah. Indeks penyumbatan tinggi akan mempercepat aliran lateks berhenti, sehingga menyebabkan hasil lateks rendah. Pada umumnya klon yang memiliki indeks penyumbatan tinggi menghasilkan produksi karet rendah, namun tidak menutup peluang terhadap genotipe yang memiliki indeks penyumbatan tinggi dan hasil lateksnya juga tinggi. Genotipe tersebut dicirikan dengan lateks mengalir cukup deras sesaat setelah dilakukan penyadapan namun aliran lateks berjalan dalam waktu relatif singkat jika dibandingkan dengan klon yang memiliki indeks penyumbatan rendah. Genotipe HP 92/366 memiliki indeks penyumbatan paling tinggi di dua musim yaitu masing-masing sebesar 32,39\% dan 40,76\%. Genotipe HP 92/179, HP 92/211, dan HP 92/711 memiliki indeks penyumbatan berbeda nyata antara bulan basah dengan bulan kering.

\section{Karakter Indeks Hasil dan Daya Hasil Lateks Beberapa Genotipe Karet Harapan}

Data hasil pengamatan pengaruh interaksi genotipe dan musim pada karakter kadar karet kering, indeks hasil dan daya hasil lateks disajikan pada Tabel 4. Terdapat interaksi genotipe $\mathrm{x}$ musim pada karakter indeks hasil dan daya hasil lateks, namun tidak terdapat interaksi genotipe $\mathrm{x}$ musim pada karakter kadar karet kering. Pengaruh interaksi ini menunjukkan bahwa respon genotipe pada karakter indeks hasil dan daya hasil sangat peka terhadap perubahan musim. Kondisi rata-rata curah hujan di bulan basah lebih tinggi dibandingkan di bulan kering diduga mempengaruhi karakter indeks hasil dan daya hasil lateks. Oleh karena itu kondisi gugur daun yang terjadi pada saat bulan kering yang menyebabkan daya hasil lateks pada masingmasing genotipe menjadiberagam.

Sebanyak 13 genotipe memiliki indeks hasil yang berbeda nyata antara bulan basah dengan bulan kering. Genotipe HP 92/179 dan HP 92/309 memiliki indeks hasil paling tinggi di bulan basah, namun terdapat penurunan indeks hasil di bulan kering yang cukup nyata

Tabel 4. Analisis sidik ragam kadar karet kering, indeks hasil dan hasil lateks 15 genotipe karet harapan.

\begin{tabular}{|c|c|c|c|c|}
\hline $\begin{array}{c}\text { Sumber } \\
\text { keragaman }\end{array}$ & $\mathrm{db}$ & $\begin{array}{c}\text { Kadar karet kering } \\
(\%)\end{array}$ & $\begin{array}{c}\text { Indeks hasil } \\
(\%)\end{array}$ & $\begin{array}{l}\text { Hasil lateks } \\
(\mathrm{g} / \mathrm{p} / \mathrm{s})\end{array}$ \\
\hline Genotipe (G) & 16 & $64,33^{* *}$ & $47,05^{* *}$ & $470,75^{\text {** }}$ \\
\hline $\operatorname{Musim}(\mathrm{M})$ & 1 & $77,06^{* *}$ & $1357,63^{\text {** }}$ & $5108,17^{* *}$ \\
\hline GxM & 16 & 6,09 & $13,01^{* \star}$ & $61,22^{\star *}$ \\
\hline Galat & 68 & 12,72 & 3,41 & 17,83 \\
\hline Total & 101 & & & \\
\hline
\end{tabular}


terdapat pada genotipe HP 92/179. Genotipe tersebut memiliki indeks hasil di bulan basah sebesar $20,35 \%$ dan menurun menjadi 9,62\% di saat bulan kering. Indeks hasil sangat ditentukan oleh lamanya hasil lateks mengalir (Woelan et al., 2013; Atminingsih et al., 2016). Ketersediaan air yang cukup pada kondisi bulan basah menyebabkan indeks hasil lebih tinggi pada bulan tersebut. Menurut Siregar (2014), indeks hasil yang lebih tinggi di bulan basah diduga tanaman memiliki kecukupan air dan daun dalam kondisi daun laten. Curah hujan tinggi diperkirakan turut memicu tingginya indeks hasil.

Genotipe HP 92/388 memiliki indeks hasil rendah di bulan basah, namun meningkat indeks hasilnya di bulan kering, namun secara statistik tidak berbeda nyata. Sedangkan genotipe HP 92/388 menunjukkan indek hasilnya meningkat pada bulan kering. Hal ini diduga genotipe tersebut memiliki respon yang cukup baik pada kondisi bulan kering. Indeks hasil yang cukup stabil di dua musim dan secara statistik tidak berbeda nyata diketemukan pada genotipe HP 92/388. Genotipe tersebut memiliki indeks hasil lebih tinggi diantara klon yang diuji dan klon pembanding PB 260 dan RRIC 100. Indeks hasil paling rendah dan berbeda nyata di dua musim terdapat pada genotipe HP 92/726 yaitu di bulan basah sebesar $11,42 \%$ dan di bulan kering sebesar $3,12 \%$.

Hasil analisis uji beda rataan menunjukkan interaksi genotipe dan musim berpengaruh nyata terhadap daya hasil lateks. Seperti halnya dengan karakter indeks hasil, rata-rata daya hasil lateks lebih tinggi di bulan basah dibandingkan dengan di bulan kering. Genotipe HP 92/309 dan HP 92/542 memiliki daya hasil lateks paling tinggi, namun secara statistik tidak berbeda nyata dengan klon PB 260 dan RRIC 100 masing-masing sebesar 49,60 gram dan 54,68 gram pada bulan basah. Sedangkan genotipe HP 92/309 terlihat lebih

Tabel 5. Pengaruh interaksi genotipe dan musim pada karakter indeks hasil dan hasil lateks 15 genotipe karet harapan.

\begin{tabular}{|c|c|c|c|c|}
\hline \multirow{2}{*}{ Genotipe } & \multicolumn{2}{|c|}{ Indeks hasil (\%) } & \multicolumn{2}{|c|}{$\begin{array}{l}\text { Daya hasil lateks } \\
(\mathrm{g} / \mathrm{p} / \mathrm{s})\end{array}$} \\
\hline & $\begin{array}{l}\text { Bulan } \\
\text { basah }\end{array}$ & $\begin{array}{l}\text { Bulan } \\
\text { kering }\end{array}$ & $\begin{array}{l}\text { Bulan } \\
\text { basah }\end{array}$ & $\begin{array}{l}\text { Bulan } \\
\text { kering }\end{array}$ \\
\hline HP 92/109 & $18,81^{\text {abcd }}$ & $11,34^{\text {ghijklmn }}$ & $34,20^{\text {cdefgh }}$ & $22,18^{\text {hijklm }}$ \\
\hline HP 92/179 & $20,35^{\mathrm{abc}}$ & $9,62^{\mathrm{ijklmn}}$ & $38,67^{\text {bcde }}$ & $20,02^{\mathrm{ijklm}}$ \\
\hline HP 92/211 & $16,38^{\text {bcdefg }}$ & $12,13^{\text {fghijklmn }}$ & $35,63^{\text {cdefg }}$ & $28,88^{\text {efghijk }}$ \\
\hline HP 92/309 & $22,69^{a}$ & $12,52^{\text {efghijklmn }}$ & $49,60^{\mathrm{ab}}$ & $28,39^{\text {efghijkl }}$ \\
\hline HP 92/327 & $15,95^{\text {bcdefgh }}$ & $7,37^{1 \mathrm{mno}}$ & $32,15^{\text {cdefghi }}$ & $28,39^{\mathrm{mn}}$ \\
\hline HP 92/366 & $15,00^{\text {bcdefghi }}$ & $8,86^{\mathrm{jklmno}}$ & $41,69^{\text {abcde }}$ & $24,50^{\text {fghijklm }}$ \\
\hline HP 92/368 & $16,52^{\text {bcdefg }}$ & $7,59^{\operatorname{lmno}}$ & $28,63^{\text {efghijk }}$ & $14,69^{\operatorname{lmn}}$ \\
\hline HP 92/388 & $13,71^{\text {defghijkl }}$ & $14,75^{\text {cdefghij }}$ & $24,17^{\text {fghijklm }}$ & $28,39^{\text {efghijkl }}$ \\
\hline HP 92/542 & $20,99^{\mathrm{ab}}$ & $16,04^{\text {bcdefgh }}$ & $54,68^{\mathrm{a}}$ & $44,81^{\mathrm{abc}}$ \\
\hline HP 92/669 & $17,61^{\text {abcdef }}$ & $8,06^{\mathrm{klmno}}$ & $41,71^{\text {abcde }}$ & $19,58^{\mathrm{ijk} k m}$ \\
\hline HP 92/677 & $14,50^{\text {cdefghij }}$ & $6,58^{\mathrm{no}}$ & $24,60^{\text {fghijklm }}$ & $12,25^{\mathrm{mn}}$ \\
\hline HP 92/704 & $12,93^{\text {defghijklm }}$ & $6,78^{\text {no }}$ & $28,10^{\text {efghijkl }}$ & $16,34^{\mathrm{klmn}}$ \\
\hline HP 92/711 & $18,41^{\text {abcde }}$ & $7,18^{\mathrm{mno}}$ & $37,16^{\text {bcdef }}$ & $16,00^{\mathrm{klmn}}$ \\
\hline HP 92/726 & $11,42^{\text {ghijklmn }}$ & $3,12^{\circ}$ & $18,36^{\mathrm{jklmn}}$ & $5,38^{\mathrm{n}}$ \\
\hline HP 92/838 & $18,76^{\text {abcd }}$ & $10,22^{\text {hijklmn }}$ & $37,54^{\text {bcdef }}$ & $20,49^{\text {hijklm }}$ \\
\hline RRIC 100 & $18,02^{\text {abcdef }}$ & $11,23^{\text {ghijklmn }}$ & $42,80^{\mathrm{abcd}}$ & $29,03^{\text {efghijk }}$ \\
\hline PB 260 & $18,60^{\mathrm{abcd}}$ & $13,22^{\text {defghijkl }}$ & $45,65^{\mathrm{abc}}$ & $30,91^{\text {defghij }}$ \\
\hline
\end{tabular}

Angka-angka pada kolom dan baris yang sama yang diikuti oleh huruf yang sama tidak berbeda nyata pada a 0,05 menurut uji $H S D$. 
peka pada kondisi bulan kering. Hal tersebut terlihat dari daya hasil lateks di bulan kering menurun cukup nyata yaitu sebesar 23,39 gram.

Genotipe HP 92/368 dan HP 92/726 memiliki daya hasil lateks paling rendah di dua musim. Genotipe HP 92/542 menunjukkan respon yang cukup baik di dua musim. Hal ini mengindikasikan bahwa genotipe HP 92/542 memiliki hasil lateks tinggi dan stabil pada kedua musim. Dengan demikian, genotipe HP 92/542 sangat potensial dikembangkan menjadi klon karet unggul harapan. Menurut Jandong et al. (2011), informasi stabilitas suatu genotipe sangat penting bagi pemulia dalam mengidentifikasi dan memilih genotipe yang penampilannya lebih baik pada kondisi lingkungan yang diberikan.

\section{Seleksi Genotipe Karet Harapan yang Stabil dan Berdaya Hasil Tinggi}

Klon karet unggul berdaya hasil tinggi diharapkan memiliki tingkat stabilitas yang tinggi. Untuk mengetahui tingkat stabilitas tanaman tersebut dapat dilakukan dengan melihat nilai ragam hasil lateks pada masing- masing genotipe. Tabel 6 dan Tabel 7 menunjukkan nilai ragam dalam genotipe, standar deviasi, dan koefisien keragaman 15 genotipe karet di bulan basah dan di bulan kering. Hubungan antara hasil lateks dengan ragam hasil lateks dalam genotipe pada beberapa genotipe karet di bulan basah disajikan pada Gambar 3. Sedangkan hubungan antara hasil lateks dengan ragam daya hasil lateks dalam genotipe di bulan kering disajikan pada Gambar 4.

Berdasarkan nilai ragam daya hasil lateks dalam genotipe di bulan basah diketahui bahwa genotipe HP 92/309 dan HP 92/542 memiliki tingkat keseragaman (homogenitas) daya hasil lateks dalam genotipe pada bulan basah (Agustus - November 2015) paling tinggi dengan $\mathrm{KK}$ sebesar $7,25 \%$ dan $8,50 \%$. Dua genotipe tersebut lebih seragam dibandingkan dengan klon pembanding $\mathrm{PB}$ 260 dan RRIC 100 (Tabel 6), sedangkan pada bulan kering genotipe HP 92/542 memiliki keseragaman hasil lateks dalam genotipe paling tinggi $(\mathrm{KK}=8,28 \%)$ dibandingkan dengan klon pembanding PB 260 dan RRIC 100 (Tabel 7). Genotipe lainnya memiliki keseragaman hasil lateks dalam genotipe pada

Tabel 6. Nilai ragam dalam genotipe, standar deviasi dan koefisien keragaman 15 genotipe karet harapan di bulan basah.

\begin{tabular}{lrrr}
\hline Genotipe & 2 & $\mathrm{Sd}$ & $\mathrm{KK}(\%)$ \\
\hline HP 92/109 & 62,74 & 7,92 & 23,16 \\
HP 92/179 & 141,63 & 11,90 & 30,77 \\
HP 92/211 & 60,94 & 7,81 & 21,91 \\
HP 92/309 & 12,92 & 3,59 & 7,25 \\
HP 92/327 & 63,57 & 7,97 & 24,80 \\
HP 92/366 & 147,27 & 12,14 & 29,11 \\
HP 92/368 & 88,21 & 9,39 & 32,86 \\
HP 92/388 & 35,73 & 5,98 & 25,08 \\
HP 92/542 & 21,61 & 4,65 & 8,50 \\
HP 92/669 & 53,14 & 7,29 & 17,47 \\
HP 92/677 & 65,21 & 8,08 & 32,89 \\
HP 92/704 & 58,34 & 7,64 & 27,19 \\
HP 92/711 & 111,35 & 10,55 & 28,40 \\
HP 92/726 & 13,52 & 3,68 & 20,14 \\
HP 92/838 & 78,70 & 8,87 & 23,63 \\
RRIC 100 & 45,57 & 6,75 & 16,50 \\
PB 260 & 94,06 & 9,70 & 22,61 \\
\hline
\end{tabular}

Keterangan : $\sigma^{2}=$ ragam, $\mathrm{sd}=$ standar deviasi, $\mathrm{KK}=$ koefisien keragaman 
Tabel 7. Nilai ragam dalam genotipe, standar deviasi dan koefisien keragaman 15 genotipe karet harapan pada bulan kering.

\begin{tabular}{lrrc}
\hline Genotipe & 2 & sd & KK $(\%)$ \\
\hline HP 92/109 & 81,17 & 9,01 & 40,06 \\
HP 92/179 & 23,83 & 4,88 & 24,35 \\
HP 92/211 & 53,55 & 7,32 & 25,26 \\
HP 92/309 & 28,23 & 5,31 & 18,62 \\
HP 92/327 & 51,55 & 7,18 & 56,59 \\
HP 92/366 & 57,06 & 7,55 & 30,75 \\
HP 92/368 & 24,86 & 4,99 & 34,07 \\
HP 92/388 & 120,21 & 10,96 & 38,35 \\
HP 92/542 & 14,01 & 3,74 & 8,28 \\
HP 92/669 & 30,49 & 5,52 & 28,76 \\
HP 92/677 & 65,64 & 8,10 & 66,83 \\
HP 92/704 & 168,28 & 12,97 & 79,04 \\
HP 92/711 & 38,09 & 6,17 & 38,76 \\
HP 92/726 & 6,67 & 2,58 & 48,85 \\
HP 92/838 & 75,30 & 8,68 & 41,90 \\
RRIC 100 & 69,54 & 8,34 & 27,98 \\
PB 260 & 14,47 & 3,80 & 12,28 \\
\hline
\end{tabular}

Keterangan : $\sigma^{2}=$ ragam, $\mathrm{sd}=$ standar deviasi, $\mathrm{KK}=$ koefisien keragaman.

bulan basah dan bulan kering tergolong rendah dengan $\mathrm{KK}>15 \%$. Nilai $\mathrm{KK}$ yang tinggi tersebut mencerminkan bahwa genotipegenotipe tersebut memiliki keragaman dalam genotipe tergolong tinggi.

Gambar 3 memperlihatkan bahwa genotipe HP 92/726, HP 92/309 dan HP 92/542 memiliki nilai ragam dalam genotipe pada bulan basah paling rendah yaitu masingmasing sebesar 13,52, 12,92 dan 21,61. Nilai tersebut menunjukkan bahwa genotipegenotipe tersebut memiliki daya hasil lateks dalam genotipe lebih seragam. Genotipe HP 92/309 dan HP 92/542 memiliki hasil lateks paling tinggi dibandingkan genotipe lainnya maupun klon pembanding.

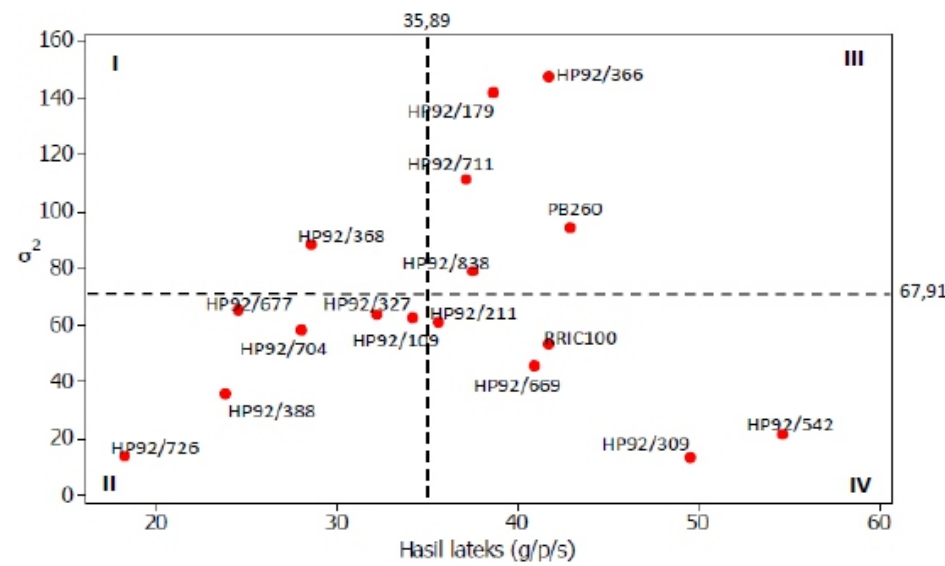

Gambar 3. Hubungan antara daya hasil lateks dengan ragam dalam genotipe dari 15 genotipe karet harapan pada bulan basah 


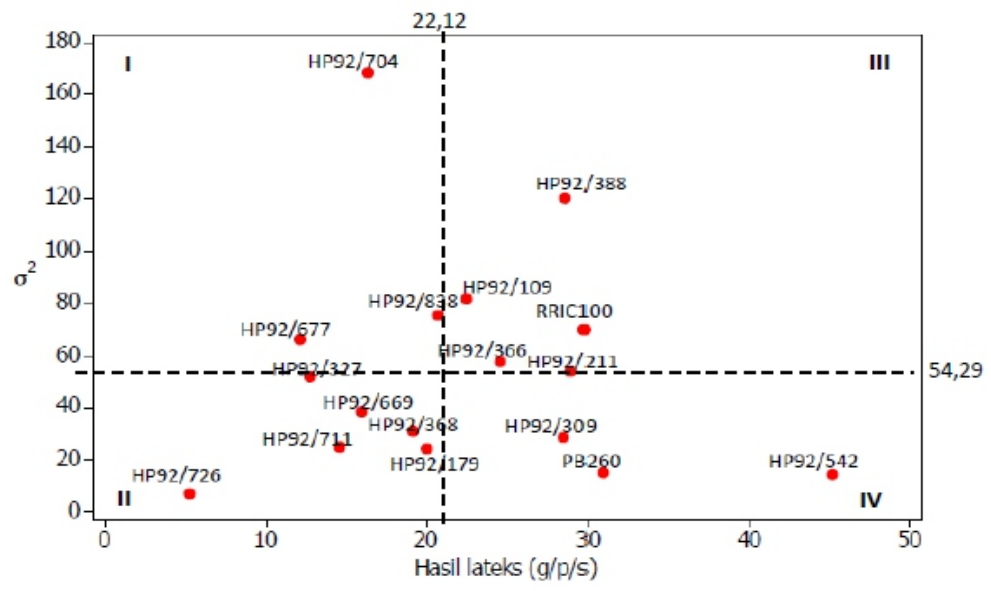

Gambar 4. Hubungan antara hasil lateks dengan ragam dalam genotipe dari 15 genotipe harapan pada bulan kering.

Pada kondisi bulan kering juga menunjukkan bahwa genotipe HP 92/542 memiliki daya hasil lateks paling tinggi dan memiliki nilai ragam rendah, sedangkan genotipe HP 92/726 memiliki nilai ragam rendah, namun daya hasil lateksnya sangat rendah (Gambar 4). Berdasarkan hubungan antara daya hasil lateks dengan ragam genotipe yang disajikan pada Gambar 3 dan 4 menunjukkan bahwa genotipe HP 92/542 memiliki daya hasil lateks paling tinggi dan stabil di dua musim. Perbedaan respon yang ditampilkan oleh setiap genotipe menunjukkan adanya interaksi antara faktor genotipe $\mathrm{x}$ lingkungan terhadap penampilan masing-masing genotipe.

\section{Kesimpulan dan Saran}

Berdasarkan hasil penelitian dapat disimpulkan bahwa karakter fisiologi lateks seperti kadar sukrosa, fosfat anorganik, tiol, kecepatan aliran lateks, indeks penyumbatan, indeks hasil, dan daya hasil lateks dipengaruhi oleh interaksi genotipe dan musim. Genotipe HP 92/542 merupakan genotipe yang lebih toleran terhadap perubahan musim dengan daya hasil lateks yang tinggi dan stabil. Diharapkan genotipe tersebut dapat dikembangkan sebagai materi genetik klon unggul baru yang toleran terhadap perubahan musim. Genotipe HP 92/726 juga toleran terhadap perubahan musim namun hasil lateksnya rendah, sedangkan genotipe HP 92/838 tidak toleran terhadap perubahan musim dengan hasil lateks rendah dan tidak stabil. Perlu dilakukan penelitian lebih lanjut mengenai mekanisme adaptasi tanaman pada masing-masing genotipe terhadap perubahan musim.

\section{Daftar Pustaka}

Ardika, R., Cahyo, A. N., \& Wijaya, T. (2016). Dinamika gugur daun dan produksi berbagai klon karet kaitannya dengan kandungan air tanah. Jurnal Penelitian Karet, 29(2), 102-109.

Atminingsih. (2015). Respon fisiologi lateks dan histologi pembuluh lateks beberapa klon terhadap konsentrasi stimulan yang berbeda pada tanaman karet (Hevea brasiliensis Muell. Arg.). (Magister Tesis), Universitas Sumatera Utara, Medan.

Atminingsih, Napitupulu, J. A., \& Siregar, T. H. (2016). Pengaruh konsentrasi stimulan terhadap fisiologi lateks beberapa klon tanaman karet (Hevea Brasiliensis Muell Arg). Jurnal Penelitian Karet, 34(1), 13-24.

Cahyo, A. N., Ardika, R., \& Wijaya, T. (2016). Konsumsi air dan produksi karet pada berbagai sistem pengaturan jarak tanam dalam kaitannya dengan kandungan air tanah. Jurnal Penelitian Karet, 29(2), 110117. 
Dische, Z. (1962). Color reactions of carbohydrates. Methods in Carbohydrate Chemistry, 1, 477-512.

Duzdemir, O. (2011). Stability analysis for phenological characteristics in chickpea. African Journal of Agricultural Research, 6(7), 1682-1685.

Gireesh, T., Raj, S., Mydin, K. K., \& Mercykutty, V. (2011). Rubber yield of certain clones of Hevea brasiliensis and its relationship with climate variables. Natural Rubber Research, 24(1), 54-60.

Gunasekera, H., De Costa, W., \& Nugawela, A. (2013). Canopy photosynthetic capacity and light response parameters of rubber (Hevea brasiliensis) with reference to exploitation. Current Agriculture Research Journal, 1(1), 01-12.

Jandong, E., Uguru, M., \& Oyiga, B. (2011). Determination of yield stability of seven soybean (Glycine max) genotypes across diverse soil $\mathrm{pH}$ levels using GGE biplot analysis. Journal of Applied Biosciences, 43, 2924-2941.

Junaidi, Sembiring, Y. R. V., \& Siregar, T. H. (2015). Pengaruh perbedaan letak geografi terhadap pola produksi tahunan tanaman karet. Warta Perkaretan, 34(2), 127-136.

Kartasapoetra, A. G. (1986). Klimatologi: Pengaruh iklim terhadap tanah dan tanaman. Jakarta, Indonesia: PT. Bina Aksara.

Kuswanto. (2007). Pemuliaan kacang panjang tahan penyakit mosaik. Malang, Indonesia Unit Pertanian Fakultas Pertanian Universitas Brawijaya.

Mattjik, A. A., \& Sumertajaya, I. M. (2006). Perancangan percobaan dengan aplikasi SAS dan Minitab. Bogor, Indonesia: Institut Pertanian(IPB)-Press.

McMullen, A. (1960). Thiols of low molecular weight in Hevea brasiliensis latex. Biochimica et Biophysica Acta, 41(1), 152-154.

Milford, G. (1969). Latex vessel plugging, its importance to yield and clonal behaviour. Journal of the Rubber Research Institute of Malaya, 21, 274-281.
Mirabello, M., Yavitt, J., Garcia, M., Harms, K. E., Turner, B. L., \& Wright, S. J. (2013). Soil phosphorus responses to chronic nutrient fertilisation and seasonal drought in a humid lowland forest, Panama. Soil Research, 51(3), 215-221.

Prihastanti, E., Tjitrosemito, S., Sopandie, D., \& Qoyim, I. (2015, 13 Juni). Pertumbuhan fineroot kakao (Theobroma cacao) pada cekaman kekeringan selama 13 bulan di kawasan agroforestri dengan pohon pelindung utama gamal (Gliricidia sepium). Tulisan disajikan pada Seminar Nasional Masyarakat Biodiversitas Indonesia, Bandung.

Purwaningrum, Y. (2016). Fisiologi dan Produksi Karet dengan Berbagai Sistem Sadap dan Penggunaan Stimulan Gas. (Doktor Disertasi), Universitas Sumatera Utara, Medan.

Roux, Y. 1., Ehabe, E., Sainte Beuve, J., Nkengafac, J., Nkeng, J., Ngolemasango, F., \& Gobina, S. (2000). Seasonal and clonal variations in the latex and raw rubber of Hevea brasiliensis. Journal of the Rubber Research Institute of Malaysia, 3(3), 142-156.

Sari, L. W., Nugrahaeni, N., Kuswanto, K., \& Basuki, N. (2013). Interaksi genotipe X lingkungan galur-galur harapan kedelai (Glycine Max (L)). Jurnal Produksi Tanaman, 1(5), 434-441.

Sayurandi. (2016). Analisis Dinamika Daya Hasil Lateks Beberapa Genotipe Karet Harapan Pp/07/04 Terhadap Perubahan Musim. (Magister Tesis), Institut Pertanian Bogor, Bogor.

Schartner, J., Gavriljuk, K., Nabers, A., Weide, P., Muhler, M., Gerwert, K., \& Kötting, C. (2014). Immobilization of proteins in their physiological active state at functionalized thiol monolayers on ATR-germanium crystals. ChemBioChem, 15(17), 2529-2534.

Sharrifmoghaddasi, M., \& Omiditabrizi, A. (2010). Stability analysis of seven Iranian winter safflower cultivars. World Applied Sciences Journal, 8(11), 1366-1369.

Siregar, T. H. (2014). Pola musiman produksi dan gugur daun pada klon PB 260 dan RRIC 100. Jurnal Penelitian Karet, 32(2), 8897. 
Sumarmadji. (1999). Respon karakter fisiologi dan produksi lateks beberapa klon tanaman karet terhadap stimulan etilen. (Doktor Disertasi), Institut Pertanian Bogor, Bogor.

Sumarmadji, \& Tistama, R. (2004). Deskripsi klon karet berdasarkan karakter fisiologi lateks untuk menetapkan sistem eksploitasi yang sesuai. Jurnal Penelitian Karet, 22(1), 16-25.

Sundari, T., Nugrahaeni, N., \& Susanto, G. W. A. (2016). Interaksi genotipe $x$ lingkungan dan stabilitas hasil biji kedelai toleran naungan. Jurnal Agronomi Indonesia, 44(1), 16-25.

Syukur, M., Sujiprihati, S., \& Yuniati, R. (2012). Teknik Pemuliaan Tanaman. Jakarta, Indonesia: Penebar Swadaya Grup.

Taussky, H. H., \& Shorr, E. (1953). A microcolorimetric method for the determination of inorganic phosphorus. Journal of Biological Chemistry, 202(2), 675685.
Wijaya, T. (1996). Aspek hidrologi pada perkebunan karet. Warta Perkaretan, 15(1), 1-6.

Woelan, S., Sayurandi., \& Irwansyah, E. (2014). Keragaman genetik tanaman karet (Hevea Brasiliensis Muell Arg) dari hasil persilangan interspesifik. Jurnal Penelitian Karet, 32(2), 109-121.

Woelan, S., Sayurandi., \& Pasaribu, S. A. (2012). Keragaan klon IRR seri 300 dan 400 di pengujian plot promosi. Warta Perkaretan, 31(1), 1-9.

Woelan, S., Sayurandi., \& Pasaribu, S. A. (2013). Karakter fisiologi, anatomi, pertumbuhan dan hasil lateks klon IRR seri 300. Jurnal Penelitian Karet, 31(1), 1-12.

Zambrosi, F. C. B., Mattos, D., Boaretto, R. M., Quaggio, J. A., Muraoka, T., \& Syvertsen, J. P. (2012). Contribution of phosphorus (32 P) absorption and remobilization for citrus growth. Plant and soil, 355(1-2), 353-362. 